\title{
The art of iltizam in the Garibiy's work
}

\section{Sulaymon HALIMOV 1}

Samarkand State University

\begin{tabular}{l} 
ARTICLE INFO \\
\hline Article history: \\
Received April 2021 \\
Received in revised form \\
20 April 2021 \\
Accepted 15 May 2021 \\
Available online \\
25 June 2021 \\
\hline
\end{tabular}

\section{Keywords:}

Iltizam,

ghazal,

ablaqsuvore,

Eid,

Ramadan,

lojuvardi,

mastonavorlik,

appointment of sweetheart,

client.

\begin{abstract}
The article deals with the art of obedience among the arts used in the work of one of the Timurid princes, Shah Gharib Mirza Gharibi. The fact that Gharibi has a high level of skill as a creator is given in detail in the way he draws large philosophical conclusions from a small detail through a means of obedience, creating unexpected images. The topic was covered by the author based on the results of experiments and research in the framework of the dissertation.
\end{abstract}

2181-1415/C 2021 in Science LLC.

This is an open access article under the Attribution 4.0 International (CC BY 4.0) license (https://creativecommons.org/licenses/by/4.0/deed.ru)

\section{Ғарибий ижодида илтизом санъати}

\footnotetext{
Калит сўзлар:

илтизом санъати, ғазал, аблақсуворе,

Ийд,

Рамазон, ложувардий, мастонаворлик, ёр висоли, муштарий.
}

\section{АННОТАЦИЯ}

Мақолада темурий шахзодаларидан бири Шох Ғариб Мирзо Ғарибий ижодида қўлланилган бадиий санъатлар орасида илтизом санъати тўғрисида сўз боради. Ғарибийнинг ижодкор сифатида юксак махорат эгаси эканлиги унинг илтизом воситасида кичик бир деталдан йирик фалсафий хулосалар чиқаришида, кутилмаган тасвирлар яратиши хақида батафсил маълумотлар берилган. Мавзу муаллиф томонидан олиб борилаётган диссертация иши доирасида тажриба ва тадқиқотлар натижасига таянган холда ёритилган.

\footnotetext{
${ }^{1}$ Researcher, Samarkand State University, Samarkand, Uzbekistan.

E-mail: Manaviyat.Sammi@mail.ru.
} 


\section{Искусство ильтизома в работе Гариби}

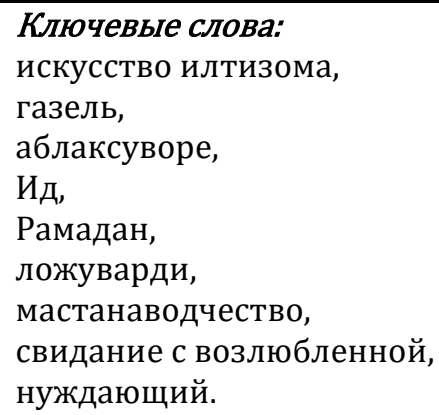

\section{АННОТАЦИЯ}

В статье говорится об искусстве илтизома среди художественных искусств, используемых в творчестве Падишаха Гариба Мирзо Гариби, одного из шахзеде темуридов. То, что Гариби является мастером своего дела как созидатель, подробно объясняется в его искусстве илтизом в выставлении больших философских выводов из мелких деталей, создании неожиданных образов. Тема освящена в рамках диссертационной работы, выполненной автором, на основе результатов эксперимента и исследований.

Темурий шахзодалардан бири Шох Ғариб Мирзо Ғарибий ижодида қўлланилган бадиий санъатлар орасида илтизом санъати ўзига хослиги билан ажралиб туради. Илтизом санъати дейилганда бир сўзни бирор парчанинг барча мисра ёки байтларида қўллаб, шу сўзнинг мухимлигини таъкидлаш тушунилади. Умуман олганда, илтизом қоидалари асосида ғазал битиш, таъкидланган сўзнинг ғазал давомида янги маъно қирраларини намоён этиши Ғарибий лирикасининг ўзига хослигини кўрсатувчи мухим хусусиятларидан бири хисобланади. Ғазалда илтизом қоидаларига кўра маълум сўзни таъкидлаш билан матн мазмунига нозик фалсафий ғояларни сингдириб юбориш, Яратганга бўлган илохий ишқ ва унга кўприк бўлувчи мажозий ишқ, хижрон туйғулари деярли хар бир ғазалда бўртиб туради. Қуйидаги ғазалга эътибор қилайлик:

Ғазал ушбу матлаъ билан бошланади:

Шахр аро аблақсуворе қилди жавлон, эй кўнгул, Бўлмағайким бўлгай ул ошуби даврон, эй кўнгул.

То курубмен тер аро чобуксуворим аблақин

Кўз қарову оқддур ашк ичра ғалтон, эй кўнгул.

Маркабидин қатра-қатра терму хар сори оқар,

Ёул аблақдур менинг холимга хайрон, эй кўнгул.

Не уёлғай ойки минди кеча гардун аблақин,

Аблақин сакратса ул хуршиди тобон, эй кўнгул.

Тун ила кун аблақин даврон менга ром айлагай,

Сурса аблақ бошима ул офати жон, эй куингул.

Куззума оқу қаро вахким курунмас, то мени,

Хусниға аблақсуворе қолди хайрон, эй кўнгул.

Хар қаёнким сурса аблақ, бўл Ғарибийдек равон,

Сен хам онинг кейнида афтонухезон, эй кўнгул.

Ғазалда шоирнинг ўз фикрларини ифодалашда асосан, “аблақ" ва "аблақсувор" сўзларини таъкидлашга кўпроқ эътибор берганлиги сезилади. Ғазалда "аблақ" сўзи 7 марта, “аблақсувор" сўзи 2 марта қўлланилган. Шуниси характерлики, ғазалда “аблақ, аблақсувор" сўзлари илтизом қоидасига кўра хар байтда такрорланиб келган ва хар байтда алохида ташбехлар, кутилмаган тасвирлар, образлар билан тобора мукаммаллашиб борган. Аблақ от ва аблақсувор 
(оқ-қора отга минган киши) сўзлари ғазалнинг дастлабки байтларида кўзнинг оқу қароси тасвирини чизса, бошқа байтда табиат ходисаларига кўчади, тунги осмондаги қоронғулигу юлдузлар ёруғлиги, яна бир байтда эса кечаю кундуз билан муқояса қилинади ва шу билан гўзал поэтик тасвир юзага келади.

Ғарибийнинг “аблақ” ва “аблақсувор” сўзларини қўллашга алохида ахамият бериши унинг бошқа ғазалларида хам кўзга ташланади. Унинг “Жилваким хар сори ул аблақсувор айлар яна, Элга ўз хуснини гуё ошкор айлар яна” деб бошланувчи ғазалида ха ёр тасвирини беришда бу сўзлардан ўринли фойдаланилган. Ғазал мазмунидан отга минган гўзалнинг жилваси , унинг ишқ ахлини беқарор холатга солганлиги, элнинг эътиборига тушганлиги махорат билан тасвирлаб берилган:

Анда чун хусну малохатдин нишоне йўтурур,
Жилва билмон не сабабдин ихтиёр айлар яна.
Жилва айлар аблақ узра бир замон тутмай қарор,
Йуқ ажаб гар ишқ ахлин беқарор айлар яна.
Жилвасин кургач йироқдин халқ аро хайрон булур,
Лек яқин етгач элни шармсор айлар яна.
Ошиқи комин берур хилватда чун ул жилвагар,
Не сабабдин эл аро андин канор айлар яна?
Хусн элидин гар уизиг кўпрак эрмас муътақид,
Сенга хардам жилва қилмоқни шиъор айлар яна.
Эй Ғарибий яна онинг жилвасидин дема сўз,
Ким бу сузлардин уизин олуфтавор айлар яна.

Ғарибий ижодида яққол кўзга ташланиб турадиган жихатлардан бири унинг ғазалларида илтизом санъатининг устуворлигидир. Шарқ мумтоз адабиётида хамма ижодкор хам илтизом билан асар яратавермаган. Бу санъат асосида асар яратиш ижодкордан юксак масъулият, тилдаги сўз ва жумлаларнинг нозик маъно қирраларини ва уларни ўз урнида қўллай билиш махоратини талаб этган. Шох Ғариб Мирзо ўзбек ва форсий тилни яхши билганлиги туфайли зуллисонайн ижодкор сифатида ўзининг ўзбек ва форс тилларидаги кўплаб ғазалларида шу санъатдан мохирона фойдалана олган. Унинг ғазалларида шу санъат воситасида ийд, май, мастлик, шикор, сайд, ложувардий тўн, нилуфарий хилъат, янги ой каби мавзулар ва сўзлар ўзларининг янгидан янги маъноларида намоён бўлган ва асарнинг поэтик охангдорлиги, образлилиги ва таъсирчанлигини таъминлашга хизмат қилган.

Шоирнинг “Ийд бўлди чобукум чун азми майдон айласа, Кош ул соат мени майдонда қурбон айласа” матлаъси билан бошланувчи ғазали мазмунини англаш китобхондан диний-ирфоний билимлардан хабардор бўлишни талаб қилади. Ғазал илтизомий санъат қоидалари асосида яратилган. Дастлабки байтдан ошиқнинг ўзини ийд куни қурбонликка чоғлагани англашилади. Ғазал мазмунини англаш учун ийд истилохига изох беришга тўғри келади. Ийд сўзининг асл мазмуни бевосита Қуръон ғояларига бориб тақалади. “Ийд” сўзи “қайтиш”, “такрорланмоқ” маъносини билдиради. Байрамлар қайта-қайта келгани учун “ийд” деб номланган. Энг мухими, икки ийд кунлари Аллох таолонинг кўплаб хайру баракаси мўминмусулмонларга қайта-қайта келади [4]. Диний нуқтаи назаридан ийд - Аллох 
таолога қилинган тоат-ибодатлар туфайли, У Зотнинг хақ йўлдаги бандаларига кўрсатган рахмату мағфирати туфайли хурсандчилик изхор қилиш учун бир муносабат сифатида талқин қилинади. Қуръоннинг "Юнус" сурасининг 58-оятида Аллох таоло: “Аллохнинг фазли ва рахмати ила. Ана шу билан хурсанд бўлсинлар. У улар жамлайдиган нарсалардан яхшидир”, деб айт”, деб мархамат қилади. Бу сўзнинг бошидаги ъайн харфининг ўзига хос махражи туфайли халқимизда “ийд” сўзи “хайит” деб талаффузи қилиш одат тусига кирган. Ийдгах - байрам тантаналари ўтказиладиган жой, ийд намози ўқиладиган жой маъносини англатади.

“Ийд улуғ ибодатни адо қилгандан сўнг бандаларга тақдим қилинган ўзига хос раббоний зиёфатдир. Ийдул Фитр Аллох таоло бандаларига Рамазон ойида фарз қилган рўза ибодати адо қилинганидан кейин келади. Банда Рамазонда Аллохнинг розилиги учун, У Зотнинг амри бўлгани учун егуликдан, ичимликдан ва рўзани очиб юборадиган бошқа нарсалардан ўзини тияди. Шунинг учун Аллох таоло ўзининг фазли, мағфирати ва бу ибодатга лойиқ кўрганидан хурсанд бўлсинлар деб бандаларини Ийдул фитр зиёфатига таклиф қилади" [5].

Мазкур фикрлардан маълум бўладики, Ислом динининг Ийд байрамларига одат нуқтаи назаридан эмас, шариат нуқтаи назаридан қаралса, бу байрамда мусулмонларнинг қалбида хайит хурсанчилиги хам, бу кунда хурсандчилик кўнглига сиғмаётган мусибатзада ва мухтожларга хамдардлик хам мужассам бўлади. Шунинг учун байрамларда мухтожларнинг кўнгли кўтарилади, мазлумларнинг хаққига дуолар қилинади. Бу икки иш ихлос билан қилинса, Аллох азза ва жаллага қурбат хосил бўлади [5]. Таърифлардан ийд сўзининг ислом динига оид тушунчани англатиши маълум бўлди. Энди ғазалга қайтамиз. Ийд куни одатга кўра хурсандчилик қилинади, қурбонликлар қилинади. Ғазалда тасвирланган ошиқ Хақ розилигига, унинг дийдорига интилган солик. Унинг орзуси "Ийд бўлди чобукум чун азми майдон айласа, Кош ул соат мени майдонда қурбон айласа”. Кўнгли Аллохга бўлган ишқ билан тўла бўлган ошиқ сархуш холатда ийд тантаналари ўтказиладиган майдонга чиқиб барчани хайрон қолдиришни истайди:

Чун сабохи ийд чиқса масту сархуш тонг эмас,

Гар юзига ийдгах ахлини хайрон айласа.

“Ийд эрур, то билмай ўткаргай мени, вах махраме,

Истарам бир қўй териси ичра пинхон айласа.

Ўзгаларга ийди васлидин тутуб жоми тараб,

Қисматим даврон нетай хуноби хижрон айласа?"

Ғазалнинг ушбу байтларида Яратган розилиги учун қурбонликка сўйилишга чоғланган Исмоилга ишора борлиги сезилади. Бу ишоралар кейинги байтларда янада тиниқлашади:

Ийдлиқ чун истадим қатлимға берди. муждае, Найлайин, ёраб, рақиб они пушаймон айласа. Ийду эл қурбон қилурда, мен ўлум холики ёр, Кош қатл айлаб мени, илкин қизил қон айласа.

Ғазалнинг охирги байтидан хақиқий ошиқнинг давоси дийдор эканлиги, шоирнинг бу мақсадга эришмасдан жон бериши қийин эканлиги англашилади: 


\section{Кўрмай ул юзни Ғарибий ўлмаки душвор эрур \\ Ийди рухсоринг не бўлди они осон айласа?}

Халқнинг расм-одатлари, анъаналари ва тушунчалари Ғарибий шеъриятида ўз ифодасини топган. Ота-боболаримиздан қолган, бугун йўқолиб бораётгандек кўринган бир ажойиб анъанамизнинг хам Ғарибий шеърларида яшаётганлиги бунга далилдир, - деб таъкидлайди Ш. Ёрқин. - Ийд-хайит кунларида катталар кичикларга, ёшлар бир-бирига ийдий (ийдлиқ, хайитлик) беришдек яхши анъана, инсонлар орасида илиқ мухаббат, самимияту қувонч тарқатиб, узилган ришталарни боғлаб, суст бўлган ришталарни тортиб, мустақкам қиларди [2].

Ғарибий ижодида мухим ўрин тутувчи тимсоллардан яна бири май хисобланади. Навоийшунос олим Э. Очиловнинг таъкидлашича, бода ва унинг май, шароб каби маънодошлари тасаввуф адабиётида илоқий тажаллий тимсоли, ишқ ва ирфон рамзи бўлиб келади. Шунга мувофиқ, мастлик илохий маърифатдан хузурланишни, маънавий завқ дарёсига ғарқ бўлишни билдиради [1]. Шоирнинг

\section{“Порсо ёримға май ичмак шиор ўлмиш яна, Баски тортармен сабу, эгним фигор ўлмиш яна"}

деб бошланувчи ғазали хам илтизом санъати асосида яратилган. Порсо сўзи луғавий жихатдан “тақводор", “художўй" маъноларини англатади. Дастлабки байтдан англашилишича, тақводор ёрнинг май ичишни одат қилиши туфайли ошиқ қўлда май идишини тутганча фигор, яъни жарохатли, мажрух, дард тортган, алам кўрган холатига тушиб қолган. Кейинги байтлар эса ошиқнинг рухий холати, ишқий ғалаён туфайли юзага келган мастонаворлик, ёр висолидан умидворлик туйғулари тасвирига бағишланган:

Базм аро то гул- гул ўлди орази, май тобидин, Ғунчадек куцнглумда пайдо хор -хор ўлмиш яна. Маст бўлғай сарви нозим вах, кўз очти уйкудин ${ }^{2}$, Май тутунг эйдўстларким, хушёр ўлмиш яна. Базм аро соқий булуб, шояд менга тутқай аёғ, Боданўшимдин кўнгул уммидвор ўлмиш яна. Бода ичмак ихтиёр айлабдурур нах не ажаб, Жавр қилмоқда агар беихтиёр ўлмиш яна. Йўқтур андин яхшиким, фикри сабухий айлагай, Кеча кўп май ичканидин чун хумор ўлмиш яна. Билмас эрдилар Ғарибийнинг нихон май ичканин, Ёри то майхора бўлди, ошкор ўлмиш яна.

Ғарибийнинг бошқа ғазалларида хам поэтик тасвирлар яратишда илтизом санъатидан махорат билан фойдаланилган. Ғарибийнинг ижодкор сифатида юксак махорат эгаси эканлиги унинг илтизом воситасида кичик бир деталдан йирик

\footnotetext{
${ }^{2}$ Кузз уйкудин.
} 
фалсафий хулосалар чиқаришида, кутилмаган тасвирлар яратишида кўринади. Унинг бу махорати Ложувардий тўнмудурким киймиш ул рашки парий, Йўқса кўкдин зохир ўлмиш офтоби ховарий” матлаъли ғазалида хам кўринади:

Осмоний тўн аро ўтлуқ юзи тердин эрур,

Кўкда қилғондек қирон хуршид бирла муштарий.

Қилди мехнат тошидин жисмимни куик бошдин оёк,

Ул ситамгарким кийибтур хилъати нилуфарий.

То нихон бўлмиш ул оташпора бухилъат аро,

Ўртаниб кул ичра пинхон бўлди кўнглим ахгари.

Кўк либос ичраким ул юз ламъаси жон куйдурур,

Барқ янглиғдурки жо қилғай булутдин хар сари.

Чиқса кўкхилъат кийиб рухсори оташнок ила,

Мунфаъил бўлғусидур гардуну гулбарги тари.

Руди Нил оқизди кузлардин Ғарибий негаким,

Жилва айлар нилгун тўн бирла онинг дилбари.

Шоир ёрини тўғридан тўғри таърифламай, эътиборини унинг либосига қаратмоқда. Ёр эгнидаги тўнни таърифлаш учун шоир “ложувардий”, “осмоний”, "кўк”, "нилуфарий”, "нилгун” каби маънодош сифатлардан фойдаланган. Ғазалда тасвирни, поэтик образлиликни кучайтириш учун ташбех, жонлантириш, муболаға каби воситалардан хам ўринли фойдаланилган.

Ғарибийнинг илтизом санъатидан фойдаланиб, маълум сўзни таъкидлаш билан унинг маъносини бутун байт ёки ғазал мазмунига сингдириб юбориши унинг "Шўхи миршикорким ишқи мени зор айламиш, Илгида кўнглум қушидурким гирифтор айламиш" матлаъли ғазалида хам кўзга ташланади. Ғазал мазмунан ов тасвирига бағишланган. Ғазалдан англашилишича, сайёд, яъни овчи шоирнинг ёри. Сайд эса унинг кўнгли. Ошиқнинг кўнгли ёр қўлига тутқун бўлган. Шу боис ошиқнинг кўнгил фарёди, рухий изтироблари ғазал мазмунига сингиб кетган:

Қуш кутаргандин илиги топмасу озор деб,

Хамнишинлар, бу алам жонимни афгор айламиш.

Эй қазо, бир сайд шакли бирла қил зохир мени,

Ким яна охингда сайд, ул кабкрафтор айламиш.

Сайдини айлар халоку мен тирик, қони ажал?

Ким тирикликни менинг жонимға душвор айламиш.

Ғазалда айниқса, ошиқнинг чорасиз холати, ёрнинг унга бепарво эканлиги қуйидаги байтларда яққол ифодаланган:

Айладим куинглумни сайду хеч парво қилмади,

Турфаким чобуксуворим сайдидин ор айламиш.

Сайди рашкидин буллурмен бисмил эткаи қуш киби,

Ким недин онинг қушиға жонни ийсор айламиш.

Эй Ғарибий, не ажаб гар қилса рам сабрим қуши,

Ким биров хажрида кўнглум нолаи зор айламиш

Шу ўринда шуни хам алохида таъкидлаш керакки, Ғарибий хар икки тилда хам бирдай ижод этганлиги боис илтизом санъатидан фойдаланиш унинг биргина ўзбек тилида ёзилган ғазалларидагина эмас, балки форсий тилдаги ғазалларида 
хам учрайди. Ғарибий ижодининг етук тадқиқотчиси Шафиқа Ёрқин бу хақда қуйидаги фикрларни билдиради ва таржималарни келтиради:

Чу Мажнун гар миёни охувон з-онам ватан бошад,

Ки рўэи сайд шояд якдам опрў сўи ман бошад.

Таржима:

Охулар ичра менинг мажнун кибидур масканим,

Токи қилгай сайд вақти бир назар сайдафганим.

Ғарибий ғазалларида илтизом фақат сўз ёки мавзуни қайтариш йўли билан эмас, нарса, холатларни англатувчи сўзларни учта-учтадан келтириш йўли билан хам юзага келтирилади. Бунинг мисолини қуйидаги ғазалда кўриш мумкин:

\section{Мажмаъи хубист имруцз аз бутони озарий, \\ Кам бувад 3-инсон қирони моху мехру муштарий. \\ Таржима: \\ Мажмаьи хусне тузибдур Озарий бутлар бугун, \\ Кам бўлур бундай қиронда муштарию ойу кун}

Юқорида матлаъ байта келтирилган ғазалда, моху мехру муштарий, зулфи сунбулу чашми наргису чехраи гулбарг, сарву шамшоду санавбар, офати ақлу балои жону ошўби дил, хуру малаку парий, жафожуву берахму ошиқкуш, нақди дину сабру хўш, учта-учта бўлган холда келиб байтларни безатади [3].

Ғарибийнинг хар бир ғазалида ўзига хос ифода, ўзига хос услуб, ўзига хос тасвирий воситалар мавжуд. Шоир бошқалар назарида эътиборсиз кўринган кичик бир деталь билан бутун бошли ғазал структурасини шакллантиради, ғазалда қўлланилган кўплаб бирликларни унга бўйсундиради ва шу тариқа ғазалда кўтарилган мавзу ва холатнинг ривожланишини таъминлайди.

“Ғарибий ўз ғазалларида мавзу ва холат вахдатани сақлашга уринади. Агар хажру ағёру интизордан сўз очилса, ғазалнинг охиригача шу мавзу ё хеч бўлмаганда шу образларга боғлик, бўлган ғам-қайғу, паришонлик, хасрат, ёлғизлик, умидсизлик каби холатлару хиссиётлар ғазалнинг охиригача давом этади, аксинча васлу вафо, дийдору тамошодан сўз бошланса, ғазалнинг охиригача қувноқ холат хукм суриб, бахтиёрлик, умидворлик ва ишонч каби туйғулар ўқувчини тарк этмайди. Айниқса, бирор сўз ё мавзу илтизоми билан ёзилган ғазалларида бундай тузилишни яққолроқ кўриш мумкин”, деб ёзади Ш. Ёрқин.

Хулоса қилиб, айтганда Ғарибий ижодида илтизом санъати ўзига хос хусусиятга эга эканлиги билан ажралиб туради.

\section{ФОЙДАЛАНИЛГАН АДАБИЁТЛАР РЎЙХАТИ:}

1. Очилов Э. Хайрат олами. http://e-adabiyot.uz/uzbek/mumoz/1272-maqola.html.

2. Шохғариб Мирзо Ғарибий. Девон. Тошкент: “Шарқ” нашриёт-матбаа акциядорлик компанияси Бош тахририяти. 2001. - Б. 21.

3. Шохғариб Мирзо Ғарибий: Девон. / Сўз боши: Ш. Ёрқин. - Т.: “Шарқ”, 2001. - Б. 17.

4. https://fiqh.uz/maqola/82. Икки ийд намози ва ташриқ такбирлари фасли.

5. https://islom.uz/maqola/5533. 